\title{
Effect of insulin-like growth factor-I treatment on serum androgens and testicular and penile size in males with Laron syndrome (primary growth hormone resistance)
}

\author{
Z Laron and B Klinger \\ Endocrine and Diabetes Research Unit, Schneider Children's Medical Center, and Sackler School of Medicine, Tel Aviv University, Tel Aviv, Israel \\ (Correspondence should be addressed to Z Laron, Endocrine and Diabetes Research Unit, Schneider Children's Medical Center, 14 Kaplan Street, \\ Petah Tikva 49202, Israel)
}

\begin{abstract}
Serum gonadotrophins, androgens, insulin and insulin-like growth factor-I (IGF-I) were determined before and during long-term treatment with recombinant IGF-I of seven males with Laron syndrome, and the changes correlated with changes in testicular volume and penile size. The subjects were four boys below the age of 5, two boys aged 10 and 14 but prepubertal and one 28 -year-old fully sexually developed adult. IGF-I was administered by a once daily subcutaneous injection of $150 \mu \mathrm{g} / \mathrm{kg}$ per day to the boys and $120 \mu \mathrm{g} / \mathrm{kg}$ per day to the adult patient.

In the very young boys no change in serum gonadotrophins, androgens, gonads or genitals was registered. In the two older boys and the adult patient, there was a progressive rise in luteinizing hormone, follicle-stimulating hormone and testosterone. Concomitantly, there was an increase in size of the testes and penile length. The two boys started puberty. As very high serum IGF-I levels were registered in the adult patient, the daily dose was progressively decreased to $70 \mu \mathrm{g} / \mathrm{kg}$ per day. Stopping the IGF-I administration in this patient, according to the protocol, led to a return to pretreatment serum levels and testicular and penile size.

This report shows for the first time a direct effect of IGF-I on sex hormones and sex organs in the male.
\end{abstract}

European Journal of Endocrinology 138 176-180

\section{Introduction}

Primary insulin-like growth factor-I (IGF-I) deficiency (Laron syndrome or primary growth hormone $(\mathrm{GH})$ resistance or insensitivity) $(1,2)$ is characterized by small testes and penis $(3,4)$. These findings indicated that in utero levels of IGF-I influence prenatal sexual development. The micropenis described in some newborns with GH deficiency (5) also seems to be due to early IGF-I deficiency. It was therefore of interest to find out whether postnatal exogenous IGF-I administration influences male sexual development.

We herewith describe for the first time the effect of long-term IGF-I treatment on serum androgens and testicular and penile size in seven males with Laron syndrome.

\section{Subjects and methods}

Seven male patients with Laron syndrome were included in this study. Their pertinent clinical data are shown in Table 1. Four boys were prepubertal, two started puberty during IGF-I treatment and one was a young adult. Patient 5 started puberty one year after the initiation of IGF-I treatment with a bone age of 8 years. Patient 6 started delayed puberty at age 16 years 6 months at a bone age of 11 years 6 months, i.e. 2 years after initiation of IGF-I treatment.

IGF-I (FK780; lots 115707K, 115807K, 710725K) synthesized by recombinant DNA technology (Fujisawa Pharmaceutical Co. Ltd, Osaka, Japan) with an identical amino acid sequence to that of natural IGF-I (6) was freshly dissolved and injected once daily by the s.c. route $15 \mathrm{~min}$ before breakfast to avoid hypoglycaemia. The boys received $150 \mu \mathrm{g} / \mathrm{kg}$ per day. The adult patient was started on a dose of $120 \mu \mathrm{g} / \mathrm{kg}$ per day, but because of a progressive increase in basal serum IGF-I levels and those at $4 \mathrm{~h}$ after the injection, the dose was progressively reduced to $70 \mu \mathrm{g} / \mathrm{kg}$ per day. In the adult patient the treatment was stopped after 9 months according to the protocol. The children were treated from 1 to 5 years. Serum samples were withdrawn in the morning after an overnight fast for measurement of all hormones, i.e. $24 \mathrm{~h}$ after the last IGF-I injection. An additional sample was taken $4 \mathrm{~h}$ after the injection to ascertain the serum IGF-I levels reached.

Serum IGF-I was measured by RIA after acid-ethanol extraction, followed by cryoprecipitation (7). Plasma 
Table 1 Pertinent clinical data of male patients with Laron syndrome at initiation of IGF-I treatment.

\begin{tabular}{lccrc}
\hline Patient & $\begin{array}{c}\text { Chronological age } \\
\text { (years) }\end{array}$ & $\begin{array}{c}\text { Bone age } \\
\text { (years) }\end{array}$ & $\begin{array}{c}\text { Height } \\
(\mathrm{cm})\end{array}$ & $\begin{array}{c}\text { Height } \\
\text { SDS }\end{array}$ \\
\hline 1 & 0.5 & 0.2 & 55.7 & -5.34 \\
2 & 3.0 & 2.0 & 76.8 & -4.54 \\
3 & 3.4 & 1.5 & 69.0 & -7.12 \\
4 & 5.0 & 1.8 & 70.5 & -7.97 \\
5 & 10.1 & 7.0 & 112.2 & -3.95 \\
6 & 14.6 & 9.0 & 110.3 & -6.50 \\
7 & 28.0 & Adult & 139.0 & -5.40 \\
\hline
\end{tabular}

SDS, standard deviation score.

insulin was measured by a double-antibody RIA with an insulin standard donated by Novo Research Institute (Novo-Nordisk, Gentofte, Denmark). $\Delta 4$-Androstenedione was measured by RIA with a kit from Diagnostic Systems Laboratories (TX, USA) dehydroepiandrosterone sulphate (DHEA-S), oestradiol and testosterone were measured by RIA with kits from Diagnostic Products Corporation (Los Angeles, CA, USA). Luteinizing hormone (LH) and follicle-stimulating hormone (FSH) were measured by immunoenzymatic assays (Dia Sorin Diagnostics s.r.l., Saluggia, Italy). Testicular size was measured by bimanual palpation using an orchidometer. The stretched penile size was measured with a caliper.

\section{Results}

The gonadotrophins, testosterone and adrenal androgen levels in the four young prepubertal boys were low and did not change during the IGF-I treatment (data not shown), nor did their small testicular volume (Fig. 1) or penile length. In the two boys aged 10 and 14 (patients 5 and 6 ), there was a progressive rise in gonadotrophins and testosterone but no change (patient 5) or a decrease (patient 6) in $\Delta 4$-androstenedione (Table 2). Concomitantly, there was an increase in size of testes (Fig. 1) and penile length. A gonadotropin-releasing hormone test was performed in patient 5 once puberty had started (testes volume $4 \mathrm{ml}$ ), and the peak serum LH was found to be $9.2 \mathrm{IU} / \mathrm{l}$.

The adult patient who started treatment at age 28 with full sexual development showed further increase in testicular size (Fig. 1) from 13 to $18 \mathrm{ml}$ and his stretched

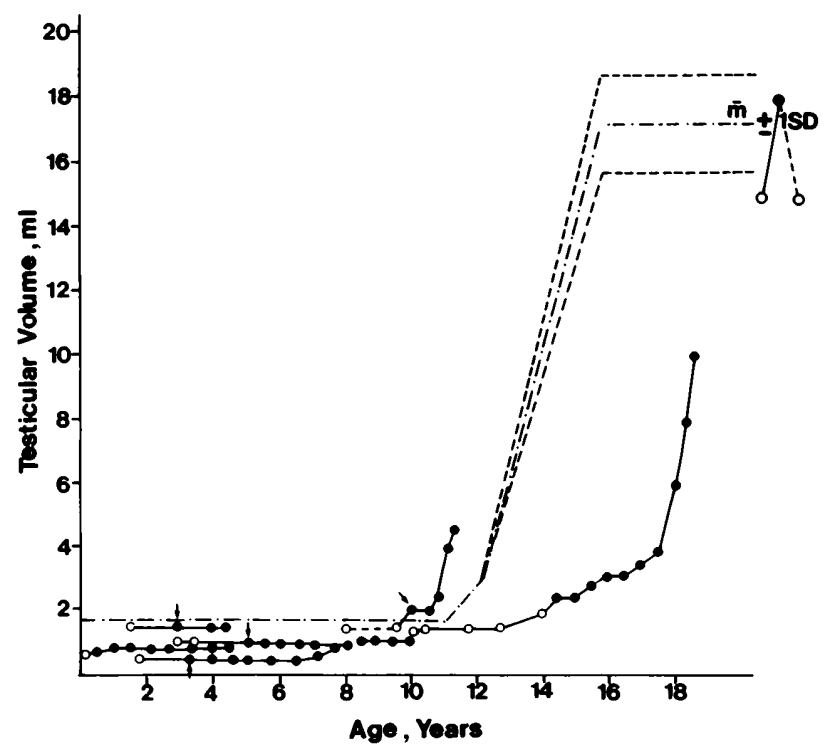

Figure 1 Testicular volume of seven male patients with Laron syndrome before $(O)$ and during $(\bullet)$ IGF-I treatment.

penile length increased from 12 to $13.5 \mathrm{~cm}$. Stopping the administration of IGF-I led to a decrease in testicular volume and penile length to the pretreatment size. The hormonal changes in this patient are shown in Fig. 2. It can be seen that the dose of IGF-I $(120 \mu \mathrm{g} / \mathrm{kg}$ per day) usually used in adult patients with Laron syndrome (8) led to an increase in serum LH and FSH, total testosterone and DHEA-S (with fluctuations) and a decrease in the mean levels of $\Delta 4$-androstenedione.

Of note is the observation that, during the period of IGF-I administration when serum IGF-I levels progressively increased, there was a reduction in insulin levels (Table 3), with a definite rise after the interruption of therapy in the adult patient. Weight changes during these periods were slight; however, there was a reduction in subscapular skinfold thickness from 27 to $17 \mathrm{~mm}$ in the adult and slightly less in the children.

\section{Discussion}

There is indirect evidence for a relationship between $\mathrm{GH}$ or IGF-I and sex hormones in man, as shown by clinical

Table 2 Serum gonadotrophins and androgen levels before and during IGF-I treatment of three male patients with Laron syndrome.

\begin{tabular}{|c|c|c|c|c|c|c|c|c|}
\hline \multirow[b]{2}{*}{ Patient } & \multicolumn{2}{|c|}{$\begin{array}{c}\text { LH } \\
(\mathrm{mlU} / \mathrm{ml})\end{array}$} & \multicolumn{2}{|c|}{$\begin{array}{c}\text { FSH } \\
(\mathrm{mlU} / \mathrm{ml})\end{array}$} & \multicolumn{2}{|c|}{$\begin{array}{l}\text { Testosterone } \\
(\mathrm{nmol} / \mathrm{l})\end{array}$} & \multicolumn{2}{|c|}{$\begin{array}{l}\Delta \text { 4-Androstenedione } \\
(\mathrm{nmol} / \mathrm{l})\end{array}$} \\
\hline & Basal & IGF-I & Basal & IGF-I & Basal & IGF-I & Basal & IGF-I \\
\hline 5 & $<0.3$ & 1.5 & 0.9 & 1.7 & $<0.7$ & 5.8 & 2.7 & 2.3 \\
\hline 6 & $<0.3$ & 1 & 0.8 & 1.8 & 0.9 & 3.8 & 4.2 & 1.9 \\
\hline 7 & 0.3 & 6 & 3.0 & 7.3 & 18.6 & 28.0 & 6.8 & 2.8 \\
\hline
\end{tabular}




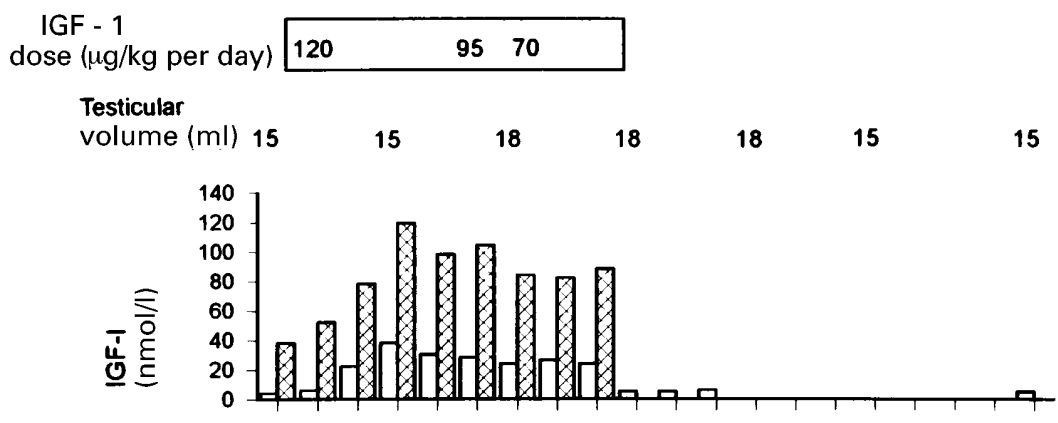

Figure 2 Serum IGF-I (basal (open bars) and $4 \mathrm{~h}$ after injection (cross-hatched bars)), insulin, androgens and gonadotrophin before, during and after IGF-I treatment of a 28-yearold patient with Laron syndrome.

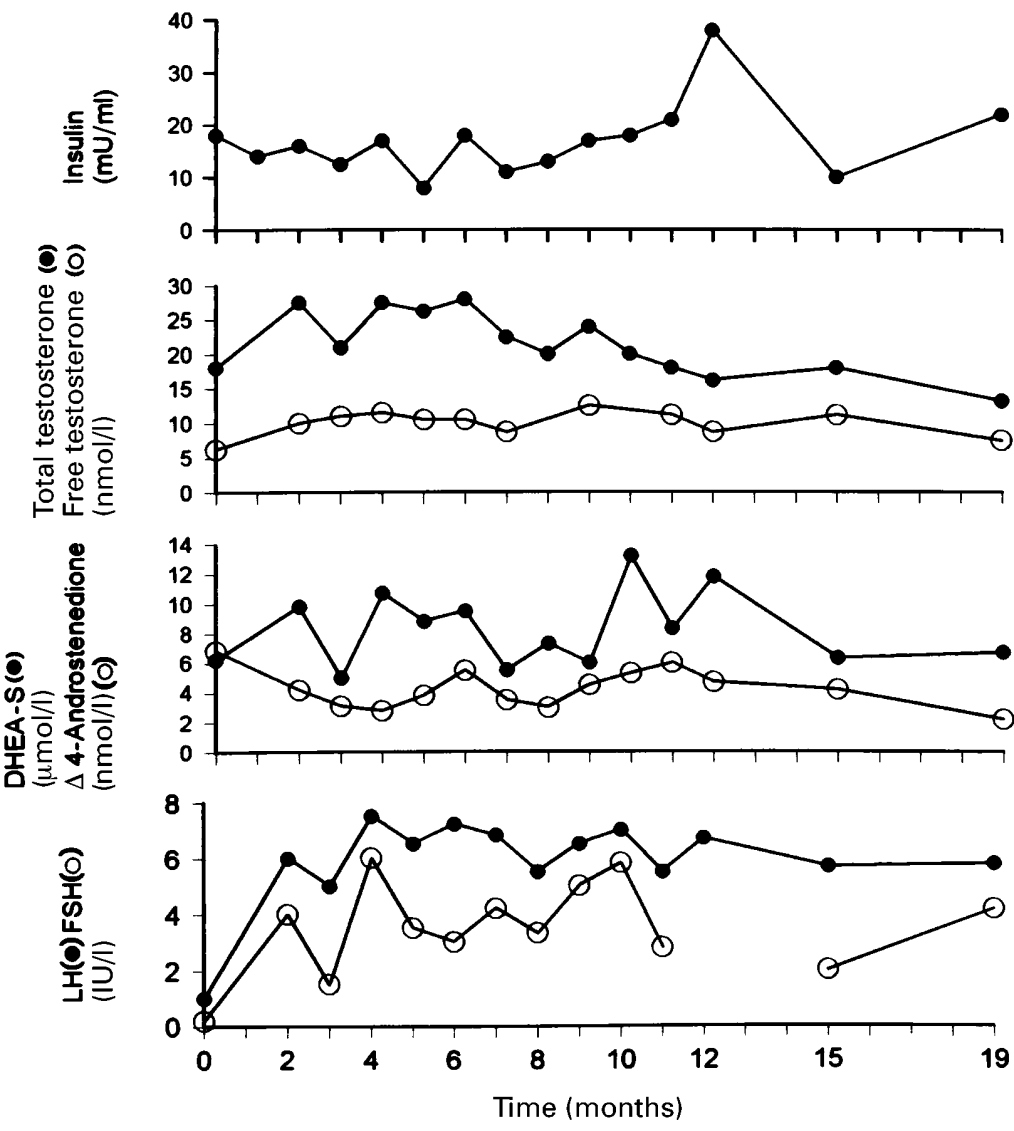

observations and laboratory data. This relationship, seemingly an interdependence on reciprocal activity, exists already in utero; thus newborns with primary IGF-I deficiency (Laron syndrome) or GH gene deletion have a small penis and testes (3-5). In the prepubertal period, the response of endogenous GH to pharmacological stimuli often becomes evident only after priming with sex hormones (10-12). During puberty the secretion of both GH and IGF-I increases $(13,14)$. Kamp et al. (15) in a recent review of available data concluded that GH treatment of prepubertal short children results in a somewhat faster rate of progression in boys and an earlier onset of puberty in girls. Children with Laron syndrome have delayed puberty which is more pronounced in boys $(16,17)$.
The present report indicates that IGF-I has a stimulating effect on gonadotrophin secretion, which in turn increases testicular testosterone secretion, without obvious effects on adrenal androgens. This effect was not observed in the four very young prepubertal boys, including one infant, but became evident in the 10- and 14-year-old boys and the adult. In the latter, who had reached full sexual development, IGF-I treatment further increased serum gonadotrophin and testosterone, with a concomitant increase in size of testes and penis. Treatment with IGF-I clearly advanced the age of onset of puberty and rate of pubertal progress in the two older boys (patients 5 and 6) when compared with previously untreated children (4) and also advanced their bone age more rapidly. 
Table 3 Serum IGF-I (basal and $4 \mathrm{~h}$ after the s.c. IGF-I injection, at the first injection and during IGF-I treatment) and basal serum insulin (before and during IGF-I treatment).

\begin{tabular}{|c|c|c|c|c|c|c|}
\hline \multirow[b]{3}{*}{ Patient } & \multicolumn{4}{|c|}{ IGF (nmol/l) } & \multicolumn{2}{|c|}{ Insulin $(\mu \mathrm{U} / \mathrm{l})$} \\
\hline & \multirow{2}{*}{$\begin{array}{c}\text { Before } \\
\text { injection } \\
\text { (O) }\end{array}$} & \multirow{2}{*}{$\begin{array}{c}\text { First } \\
\text { injection } \\
(4 \mathrm{~h})\end{array}$} & \multicolumn{2}{|c|}{$\begin{array}{l}\text { Long-term } \\
\text { IGF-I }\end{array}$} & \multirow[b]{2}{*}{$\mathrm{O}$} & \multirow{2}{*}{$\begin{array}{l}\text { Long-term } \\
\text { IGF-I } \\
\text { (Basal) }\end{array}$} \\
\hline & & & Basal & $4 \mathrm{~h}$ & & \\
\hline 5 & 2.7 & 34 & 10 & 56 & 7 & 9 \\
\hline 6 & 4.7 & 24 & 11 & 54 & 11 & 3 \\
\hline 7 & 5.5 & 37 & 38 & 119 & 19 & 9 \\
\hline
\end{tabular}

O, Overnight fasting before first IGF-I injection; Basal, overnight fasting.

The changes in serum FSH and androgens occurred concomitantly with a dramatic rise in basal serum levels of IGF-I and those observed $4 \mathrm{~h}$ after IGF-I injection (as seen in Fig. 2), reaching supraphysiological levels. Reduction of the daily IGF-I dose from $120 \mu \mathrm{g} / \mathrm{kg}$ to 95 and $70 \mu \mathrm{g} / \mathrm{kg}$ resulted in a parallel reduction in total testosterone. With the interruption of treatment in the adult patient, there was a fall in serum total testosterone, DHEA-S, FSH and LH and a reduction in testicular and penile size to pretreatment measurements. These data prove that the rise in IGF-I is the inducing stimulus for the rise in sex hormone secretion. This was also demonstrated in a previous study (9) in which we reported that four of six female patients with Laron syndrome (two girls and two young adults) progressively developed clinical signs of hyperandrogenism (oligo/amenorrhoea and acne) during IGF-I treatment. Laboratory determinations showed significant elevations in the serum LH/FSH ratio, testosterone and $\Delta 4$ androstenedione. The hyperandrogenism occurred concomitantly with a rise in serum IGF-I to supraphysiological levels $4 \mathrm{~h}$ after injection. Reduction of the IGF-I dose or interruption of the IGF-I treatment restored androgen levels to normal values, and the clinical signs of hyperandrogenism disappeared. It is of interest that, in the females, IGF-I treatment also caused a rise in serum $\Delta 4$-androstenedione concentration, whereas in the males this level decreased (in two patients) or did not change (in one patient). It is possible that this was related to serum IGF-I levels, which were higher in the females. The effect of IGF-I on serum DHEA-S, the regulation of the secretion of which is not known, was variable.

The androgen stimulation registered during longterm IGF-I administration in both males and females (9) occurred in parallel with suppression of insulin secretion and cannot therefore be attributed to this hormone, as was suggested in the case of polycystic ovary syndrome $(18,19)$.

The present and our previous report on female patients with Laron syndrome demonstrate that pharmacological levels of IGF-I encountered during IGF-I treatment induce hyperandrogenism. These effects were shown to be dose-dependent. As there was also a rise in both gonadotrophins, $\mathrm{LH}$ and FSH, it is probable that the primary effect of IGF-I is on the gonadostat. This may also explain the lack of effect on androgens, gonads and genitalia in very young prepubertal children. On the other hand a direct effect of IGF-I on the sex hormone-producing cells cannot be excluded, IGF-I receptors having been found in granulosa cells (20), and a rise in circulating IGF-I may be able to enhance the action of FSH on Sertoli and Leydig cells $(21,22)$.

\section{Acknowledgements}

The clinical trials were made possible by the generous support (to Z L) of the Fujisawa Pharmaceutical Co. Ltd, Osaka, Japan. The authors wish to thank the Endocrine Laboratory-Beilinson Hospital, headed by Yardena Nordenberg, $\mathrm{PhD}$, for performing the androgen determinations. $\mathrm{Z} \mathrm{L}$ is the incumbent of the Irene and Nicholas Marsh Chair of Endocrinology and Juvenile Diabetes, Tel Aviv University, Israel.

\section{References}

1 Laron Z, Pertzelan A \& Mannheimer S. Genetic pituitary dwarfism with high serum concentration of growth hormone. A new inborn error of metabolism? Israel Journal of Medical Sciences 1966 2 152-155.

2 Laron Z. Prismatic cases: Laron syndrome (primary growth hormone resistance). From patient to laboratory to patient. Journal of Clinical Endocrinology and Metabolism $1995801526-$ 1531.

3 Laron Z \& Sarel R. Penis and testicular size in patients with growth hormone insufficiency. Acta Endocrinologica 197063 625-633.

4 Laron Z, Pertzelan A, Karp M, Keret R, Eshet R \& Silbergeld A. Laron syndrome: a unique model of IGF-I deficiency. Pediatric and Adolescent Endocrinology 199324 3-23.

5 Goodman HG, Grumbach MM \& Kaplan SL. Growth and growth hormone. II. A comparison of isolated growth hormone deficiency and multiple pituitary hormone deficiencies in 35 patients with idiopathic hypopituitary dwarfism. New England Journal of Medicine 1968278 57-68.

6 Niwa M, Sato Y, Saito Y, Uchiyama F, Ono H, Yamashita M et al. Chemical synthesis, cloning and expression of genes for human 
somatomedin C (insulin like growth factor I) and 59Val somatomedin C. Annals of the New York Academy of Sciences 1986469 $31-52$.

7 Silbergeld A, Litwin A, Bruchis S, Varsano I \& Laron Z. Insulinlike growth factor (IGF-I) in healthy children, adolescents and adults as determined by a radioimmunoassay specific for the synthetic 53-70 peptide region. Clinical Endocrinology 198625 $67-74$.

8 Laron Z \& Klinger B. IGF-I treatment of adult patients with Laron syndrome: preliminary results. Clinical Endocrinology 199441 631-638.

9 Klinger B, Anin S, Silbergeld A, Eshet R \& Laron Z. Development of hyperandrogenism during treatment with insulin-like growth factor-I (IGF-I) of female patients with Laron syndrome. Clinical Endocrinology 199848 (In Press).

10 Martin LG, Clark JW \& Connor TB. Growth hormone secretion enhanced by androgens. Journal of Clinical Endocrinology and Metabolism 196828 425-428.

11 Illig R \& Prader A. Effect of testosterone on growth hormone secretion in patients with anorchia and delayed puberty. Journal of Clinical Endocrinology and Metabolism 197030 615-618.

12 Lippe B, Wong SLR \& Kaplan SA. Simultaneous assessment of growth hormone and ACTH reserve in children pretreated with diethylstilbestrol. Journal of Clinical Endocrinology and Metabolism 197133 949-956.

13 Mauras N, Blizzard RM, Link K, Johnson ML, Rogol AD \& Veldhuis JD. Augmentation of growth hormone secretion during puberty: evidence for a pulse amplitude modulated phenomenon. Journal of Clinical Endocrinology and Metabolism 1987 64 596-601.

14 Silbergeld A, Lazar L, Erster B, Keret R, Tepper R \& Laron Z. Serum growth hormone binding protein activity in healthy neonates, children and young adults: correlation with age, height and weight. Clinical Endocrinology 198931 295-303.
15 Kamp GA, Reckers-Mombarg LTM \& Wit JM. Does GH treatment affect pubertal timing in children with idiopathic short stature? Highlights 19975 12-15.

16 Laron Z, Sarel R \& Pertzelan A. Puberty in Laron-type dwarfism. European Journal of Pediatrics 1980134 79-83.

17 Pertzelan A, Lazar L, Linger B \& Laron Z. Puberty in fifteen patients with Laron syndrome: a longitudinal study. Pediatric and Adolescent Endocrinology 199324 27-33.

18 Barbieri RL, Smith S \& Ryan K. The role of hyperinsulinemia in the pathogenesis of ovarian hyperandrogenism. Fertility and Sterility 198850 197-212.

19 Willis D \& Franks S. Insulin action in human granulosa cells from normal and polycystic ovaries is mediated by the insulin receptor and not the type-I insulin-like growth factor receptor. Journal of Clinical Endocrinology and Metabolism $1985803788-$ 3790.

20 Bergh C, Olsson JH \& Hillensjo T. Effect of insulin-like growth factor-I on steroidogenesis in cultured human granulosa cells. Acta Endocrinologica 1991125 177-185.

21 Shoham Z, Conway GS, Ostergaard H, Lahlon N, Bouchard P \& Jacobs HS. Cotreatment with growth hormone for induction of spermatogenesis in patients with hypogonadotropic hypogonadism. Fertility and Sterility 199257 1044-1055.

22 Breier BH, Vickers MH, Gravance CG \& Casey PJ. Growth hormone $(\mathrm{GH})$ therapy markedly increases the motility of spermatozoa and the concentration of insulin-like growth factor I in seminal vesicle fluid in the male GH-deficient dwarf rat. Endocrinology 1996137 4061-4064.

Received 25 August 1997

Accepted 20 October 1997 